PONTIFÍCIA UNIVERSIDADE CATÓLICA DO RIO DE JANEIRO

Valor da marca Oi para clientes do Rio de Janeiro

Bianca Prado Godoi

Trabalho de Conclusão de Curso

Centro de ciênCias Sociais - CCS

DEPARTAMENTO dE AdMINISTRAÇÃO

Graduação em Administração de Empresas

Rio de Janeiro, Junho de 2019. 


\title{
Valor da marca Oi para clientes do Rio de Janeiro
}

\author{
Trabalho de Conclusão de Curso
}

Trabalho de Conclusão de Curso, apresentado ao programa de graduação em Administração da PUC-Rio como requisito parcial para a obtenção do titulo de graduação em Administração.

Orientador: Daniel Kamlot

Rio de Janeiro, Junho de 2019. 
"Em média, os consumidores são expostos a 6 mil anúncios por dia e a mais de 25 mil novos produtos por ano. As marcas ajudam os consumidores a atravessar esse mar de escolhas disponíveis em cada categoria de produto ou serviço".

Scott M. Davis 


\section{Agradecimentos}

Agradeço aos meus pais pela oportunidade de cursar graduação em uma universidade de excelência como a PUC - Rio e todo o incentivo dedicado a mim.

Também sou extremamente grata por todos os professores que passaram por toda a minha caminhada dentro da PUC - Rio, do primeiro ao último período e contribuíram para a minha formação.

Obrigada em especial ao meu professor e orientador Daniel Kamlot, que esteve sempre disposto e dedicado na orientação deste projeto de monografia da melhor forma possível. 


\section{Resumo}

Godoi, Bianca. Estudo sobre o valor de marca Oi para os clientes do Rio de Janeiro. Rio de Janeiro, 2019. 30 p. Trabalho de Conclusão de Curso - Departamento de Administração. Pontifícia Universidade Católica do Rio de Janeiro.

O trabalho foi feito com o intuito de medir o valor da marca Oi para os clientes do Rio de Janeiro por meio do Brand Equity. Foi estudado o cenário presente do mercado de telefonia, com foco na empresa Oi. Para aferir o valor da marca Oi, foi realizada uma pesquisa em forma de questionário relacionando os conceitos de Brand Equity com aspectos da empresa estudada. Foram estudados também, conceitos como comportamento do consumidor e marketing de serviços e as suas relações com a lealdade dos consumidores a marca.

Palavras chave:

Marketing, Brand Equity, serviços, telefonia, Oi, valor de marca. 


\begin{abstract}
Godoi, Bianca. Study about the value of brand Oi for the customers of Rio de Janeiro. Rio de Janeiro, 2019. 30 p. Course Completion Work - Administration Department. Pontifical Catholic University of Rio de Janeiro.

The work was done with the purpose of measuring the value of the Oi brand for the customers of Rio de Janeiro through Brand Equity. In order to assess the value of the Oi brand, a survey was conducted in the form of a questionnaire relating Brand Equity concepts to aspects of the company studied. We also studied concepts such as consumer behavior and service marketing and their relationship with brand loyalty.
\end{abstract}

Key words:

Marketing, Brand Equity, services, telephony, $\mathrm{Hi}$, brand value. 


\section{Sumário}

Lista de Gráficos VIII

1 O tema e o problema de estudo 1

1.1 Introdução ao tema e ao problema do estudo 1

1.2. Objetivo do estudo 1

1.3. Objetivos intermediários do estudo 2

1.4. Delimitação e foco do estudo 2

1.5. Relevância do estudo 2

2 Referencial Teórico 3

2.1.Brand Equity 3

2.2.Valor da Marca 5

2.3. Comportamento do consumidor 6

2.4. Marketing de serviços 9

3 Metodologia 10

3.1. Tipo de Pesquisa 10

3.2. Universo e amostra da pesquisa 10

3.3 Coleta de dados 10

3.4 Tratamento dos dados 11

3.5 Limitações do método 11

4 Análise de resultados 12

4.1 Perfil dos respondentes 12

4.2 Lealdade à marca $\quad 15$

$\begin{array}{ll}4.3 \text { Consciência do nome } & 16\end{array}$

$\begin{array}{lr}\text { 4.4 Qualidade percebida } & 18\end{array}$

4.5 Associações da marca 20

4.6 Outros ativos da empresa 22

$\begin{array}{ll}4.7 \text { Brand Equity } & 24\end{array}$

5 Conclusão 25

6. Referências bibliográficas $\quad 27$

$\begin{array}{ll}\text { Anexo } 1 \text { (Questionário) } & 28\end{array}$ 


\section{Lista de Figuras}

Figura 1 - Modelo de Brand Equity de Aaker 3

Figura 2 - Relações entre valor da marca e cliente ........................................................ 5

Figura 3 - Modelo de comportamento de compra.......................................................... 7

\section{Lista de Gráficos}

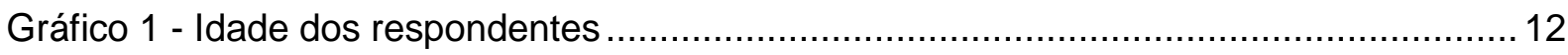

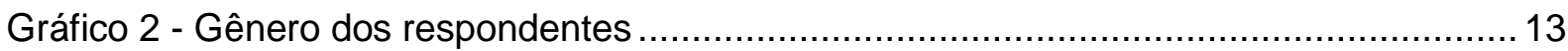

Gráfico 3 - Nível de escolaridade dos respondentes ...................................................... 13

Gráfico 4 - Renda familiar dos respondentes ................................................................ 14

Gráfico 5 - Antiguidade do cliente na empresa Oi ........................................................ 14

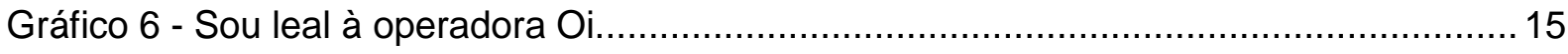

Gráfico 7 - Não trocaria a operadora Oi por outra concorrente, mesmo se a concorrente me

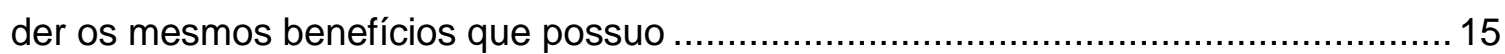

Gráfico 8 - Não trocaria a operadora Oi por outra concorrente, mesmo se a concorrente me der melhores benefícios que possuo ........................................................... 16

Gráfico 9 - Conheço todos os serviços oferecidos pela empresa Oi ................................. 17

Gráfico 10 - Conheço posicionamento de marca da operadora Oi ...................................... 17

Gráfico 11 - Conheço as causa apoiadas pela operadora Oi .............................................. 18

Gráfico 12 - A operadora Oi possui diferenciais superiores aos seus concorrentes ............. 19

Gráfico 13 - Os planos da operadora Oi dão mais vantagens que os das concorrentes ...... 19

Gráfico 14 - O serviço prestado pela operadora Oi é superior ao das concorrentes ............20

Gráfico 15 - Conheço a logo da operadora Oi............................................................... 21

Gráfico 16 - Conheço o slogan da operadora Oi .......................................................... 21

Gráfico 17 - Sei dizer qual é o comercial de TV atual da operadora Oi ................................ 22

Gráfico 18 - Sei dizer o nome de dois atletas que são ou já foram patrocinados pela empresa

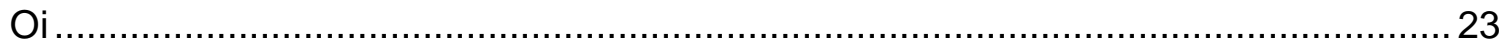

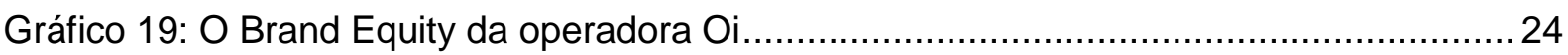




\section{0 tema e o problema de estudo}

\subsection{Introdução ao tema e ao problema do estudo}

A Oi passa por situações financeiras turbulentas e, em 20 de junho de 2016, realiza o pedido de Recuperação Judicial. A empresa cumpriu inúmeras etapas exigidas e em 8 de janeiro de 2018 teve a aprovação de seu plano de Recuperação Judicial por ampla maioria das quatro classes de credores. Em 28 de janeiro de 2019 recebeu um aumento de capital de 4 bilhões de reais, que segundo o presidente da companhia, Eurico Teles, será fundamental e essencial para mostrar ao mercado a robustez e capacidade da empresa (Oi 2019).

Segundo a Agência Nacional de Telecomunicações (2018), a telefonia fixa apresenta queda de 4,98\% nos últimos 12 meses. Em geral, todas as grandes operadoras tiveram queda. Nesse mesmo período, houve aumento de 2.346.172 de contratos de banda larga (+8,24\%). O mercado de TV por assinatura desligou 136,8 mil conexões e somou 17,6 milhões de acessos $-2,9 \% 2018$ com 2017. A Oi foi a única operadora que teve ganho líquido positivo, adicionando 3 mil conexões. Ela somou 1,6 milhões de acessos e mantém o terceiro lugar em participação, com $9,1 \%$ de market share $(+0,9 \%$ ano contra ano). De acordo também com a ANATEL (março 2019), a banda larga fixa registra aumento de 6,1\% em 12 meses. A operadora Oi possui 8,95\% do mercado nacional, ocupando o quinto lugar no ranking de participação. Esses percentuais refletem o cenário atual do consumo dos clientes em relação a produtos de telefonia e ilustra o fato de o setor ser instável e a necessidade que ele possui de se reinventar.

A Oi está no 13ํㅣㅁ lugar no ranking de empresas com mais reclamações no site ReclameAqui (2019), ficando melhor colocada que suas concorrentes Vivo, Tim e Claro, que encontram-se em $3^{\circ}, 5^{\circ}$ e $12^{\circ}$ lugar respectivamente. Os itens mais reclamados pelos clientes no site são: cobrança indevida, mau atendimento, qualidade da internet, cancelamento e demora na execução.

Tendo em vista a instabilidade do mercado, a situação complexa da companhia e o valor de marca, este trabalho visa responder: qual o valor atual da marca Oi para os clientes do Rio de Janeiro?

\subsection{Objetivo do estudo}


O objetivo deste estudo é medir o Brand Equity de uma das maiores e mais importantes empresas de telecomunicações do Brasil, a Oi. Por meio dele serão identificadas as percepções que os consumidores do Rio de Janeiro possuem a respeito da empresa e os valores representados pela mesma.

\subsection{Objetivos intermediários do estudo}

Para o atingimento do objetivo final do estudo, estão previstos como objetivos intermediários a serem alcançados:

$\checkmark$ Avaliar a força da logo da operadora Oi.

$\checkmark$ Mensurar qualidade do serviço prestado pela operadora em relação a seus concorrentes.

$\checkmark$ Medir os componentes do Brand Equity Aaker (1998) - lealdade à marca, consciência do nome, qualidade percebida, associações da marca e outros ativos da empresa da empresa Oi.

\subsection{Delimitação e foco do estudo}

O estudo terá foco apenas na empresa de telefonia Oi e não irá avaliar o Brand Equity e as percepções de clientes de outras empresas do país ou do mundo. Ele será delimitado aos consumidores apenas da empresa Oi que moram no Rio de Janeiro. Não serão levados em consideração gênero, idade, classe econômica dos clientes nem tipos de produtos/planos contratos por eles, como por exemplo, planos de TV, banda larga e voz. Todos os clientes são tratados como clientes $\mathrm{Oi}$, independente do plano que possuem em contrato. Serão levados em consideração apenas clientes do segmento B2C.

\subsection{Relevância do estudo}

Este estudo tem grande relevância para a Oi e também para as suas empresas concorrentes, ou seja, para o mercado de telefonia como um todo, já que por meio dele, a Oi e outras empresas de telecomunicações conhecerão as percepções dos consumidores em relação a um grande player desse setor, que é a empresa Oi. A importância se dá também pelo fato de que será possível identificar o Brand Equity e seus desdobramentos da empresa em estudo. A Oi irá identificar quais são os pontos nos quais se destaca em relação à concorrência e em quais deve ter maior atenção do ponto de vista de seus clientes. As suas concorrentes poderão conhecer os diferenciais da Oi e repensarem as suas estratégias levando em consideração isso. Os clientes de telecomunicações e da Oi 
em particular terão inputs para avaliação de valor de marca da empresa e o estudo dará base para uma possível ativação, troca ou cancelamento de plano.

\section{Referencial Teórico}

Neste capítulo serão abordados e discutidos assuntos relacionados ao tema principal, que embasarão a análise.

Os assuntos serão: brand equity, valor da marca, comportamento do consumidor e marketing de serviços.

\subsection{Brand Equity}

De acordo com Aaker (1998) os conceitos do Brand Equity estão divididos em cinco categorias, como mostrado na figura 1.

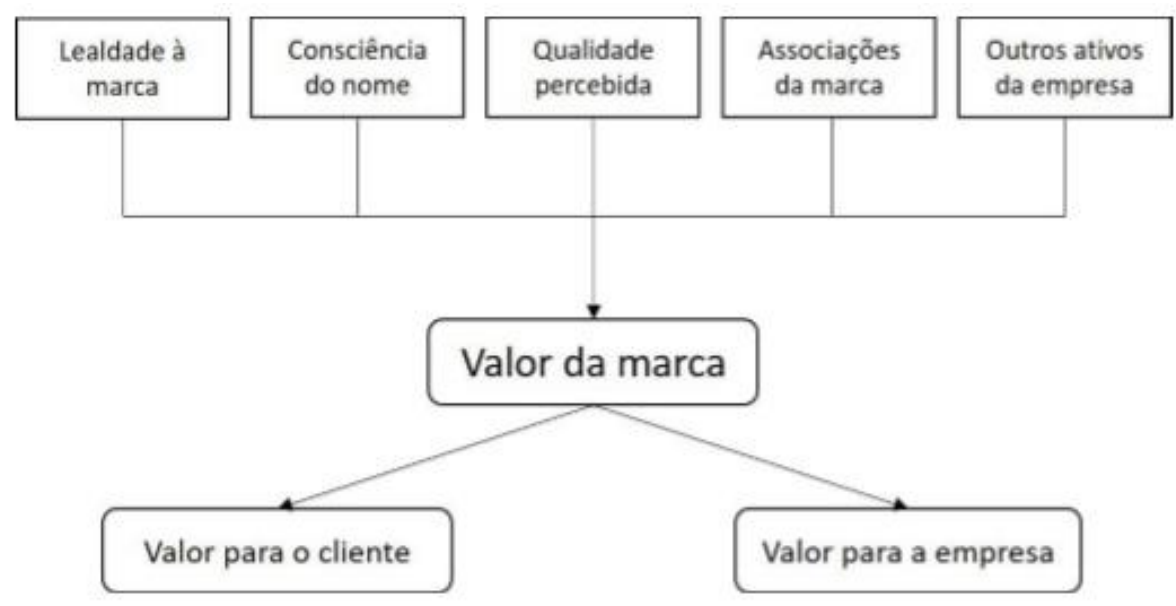

Figura 1 - Modelo de Brand Equity de Aaker

Fonte: Aaker (1998)

Para o autor, essas categorias são tidas como a base do Brand Equity, que para ele são responsáveis por gerar valor tanto para o consumidor (valor para o cliente) quanto para a organização (valor para a empresa).

- Lealdade à marca:

Capacidade de manter o cliente cativo mesmo com toda a concorrência e ofertas semelhantes, é a ligação entre o consumidor e a marca.

- Consciência do nome:

O reconhecimento percebido pelos consumidores relacionados à marca, seja tangível, seja intangível. 
- Qualidade percebida:

A diferenciação de superioridade em relação aos concorrentes. Ela possui grande influência na decisão de compra do consumidor.

- Associações da marca:

Associações diretas ou indiretas de marca presentes na memória do consumidor.

- Outros ativos da empresa:

Vantagens competitivas, como marcas registadas, patentes e relações da empresa com terceiros.

Para Aaker (1998), o Brand Equity é um conjunto de ativos e passivos ligados a uma marca, seu nome e seu símbolo, que se somam ou se subtraem do valor proporcionado por um produto ou serviço para uma empresa. Para que certos ativos e passivos determinem o Brand Equity, eles devem estar ligados ao nome e/ou símbolo da marca. Se o nome da marca ou símbolo for mudado, alguns ou todos os ativos poderão ser afetados ou mesmo perdidos. O Brand Equity proporciona valor para o consumidor por meio de aumento de sua interpretação, processamento de informação, maior confiança na decisão de compra e satisfação de uso. Já para a empresa, pela eficiência e eficácia das ações de marketing, lealdade à marca, preços, vantagem competitiva e extensões de marca (Aaker 1998).

De acordo com Keller e Machado (2005), é importante que a marca tenha associações fortes, favoráveis e únicas. Para ele, os pilares do Brand Equity são a lembrança da marca e identidade de marca. Aaker (1998) afirma que a marca possui alta influência nas avaliações dos clientes em relação a produtos e serviços, sendo capaz então, de diferenciar as organizações em um mundo repleto de opções. Para ele, o consumidor estará mais propenso a consumir tal serviço, se possuir referências positivas relacionadas a marca. De acordo com a Pirâmide do Conhecimento de Aaker (1998), o conhecimento de uma marca possui quatro níveis, sendo eles: desconhecimento - consumidor não sabe identificar a marca; reconhecimento - consumidor reconhece a marca depois de estímulos; lembrança - a marca é lembrada sem estímulos; e finalmente o top of mind - marca é a primeira a ser lembrada pelo consumidor quando se fala sobre a categoria a qual ela faz parte.

Já Rust, Lemon e Zeithaml (2004) pontuam a centralidade do cliente. Nesse sentido, as ações de marketing buscam à maximização de valor do cliente. De acordo com os autores, o valor do cliente é conduzido por Valor para o cliente (Value Equity), Marca (Brand Equity) e Relacionamento (Retention Equity). (Figura 2). 


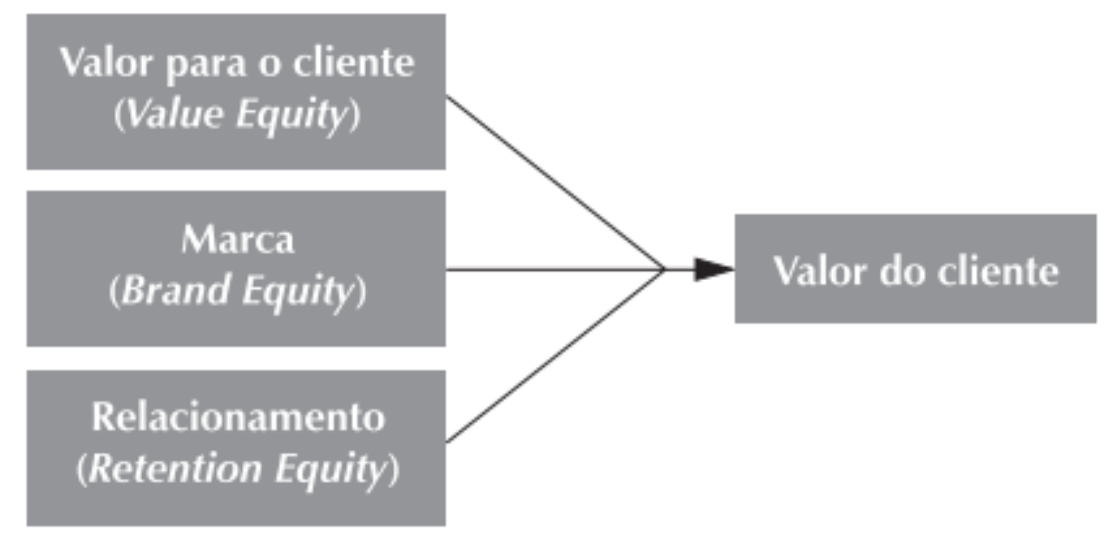

Figura 2 - Relações entre valor da marca e cliente

Fonte: Rust, Zeithaml, Lemon (2001

De acordo com Rust, Lemon e Zeithaml (2004), o valor para o cliente (Value Equity) é a avaliação objetiva feita pelo cliente a respeito da utilidade de uma marca, com base em percepções daquilo que é dado em troca do que é recebido. O valor da marca (Brand Equity) é definido como a avaliação subjetiva e intangível da marca pelo consumidor. Já o Relacionamento (Relationship Equity) é referente à tendência de o cliente permanecer com a marca, além e acima de suas avaliações objetivas e subjetivas a respeito da marca.

\subsection{Valor da Marca}

Segundo Kotler (2004), uma marca é um nome, termo, signo, símbolo ou design, ou uma combinação destes, que tem a função de identificar os bens ou serviços de concorrentes. Para ele, uma marca bem sucedida carrega seis níveis de significados.

- Atributos: a marca traz à mente do consumidor algumas características: um automóvel de luxo bem construído, com boa engenharia, duráveis e de alto prestígio;

- Benefícios: os atributos devem ser traduzidos em benefícios emocionais e funcionais, como a durabilidade de um bem e a não necessidade de adquirir outro por um determinado tempo;

- Valores: o valor que simboliza na mente do consumidor e representa em termos éticos da empresa para com o consumidor. Não trata-se do valor monetário;

- Cultura: a marca significa muito mais do que a existência do produto, a cultura de onde vem o produto deixa muito claro a expectativa do consumidor e gera satisfação ao entregar o que têm em seu significado; 
- Personalidade: a marca é capaz de projetar uma personalidade, como poder, dedicação, perfeição, força etc.;

- Usuário: público-alvo ou consumidor do produto, deixando bem clara a segmentação feita pela empresa.

A imagem da marca, segundo Keller e Machado (1993), é definida como percepções refletidas por associações de marca e contidas na memória do consumidor, ou seja, o significado que a marca representa para os consumidores. Essa imagem é construída por associações feitas pelos consumidores relacionadas a atributos do produto/serviço, como preço, embalagem, benefícios funcionais e experienciais e também benefícios simbólicos. Keller e Machado (2005) apontam que a marca é capaz de diferenciar um produto/serviço de outro existente, que atende a uma mesma necessidade. Churchill e Peter (2000) também citam o uso da marca como uma ferramenta para distinguir os produtos/serviços na mente dos possíveis compradores, concluindo que tal falto é capaz de fazer com que consumidor dedique maior esforço para escolha de tal marca. De acordo com Kotler (2006), todas as empresas lutam para estabelecer uma marca sólida - ou seja, uma imagem de marca forte e favorável.

Segundo Kotler (2006) já não basta simplesmente satisfazer clientes, é preciso encantá-los. Para o autor, a satisfação consiste na sensação de prazer ou desapontamento resultante da comparação do desempenho (ou resultado) percebido de um produto em relação às expectativas do comprador.

Para Levy e Grewal (2017), uma marca é à base de diferenciação do produto no sentido da vantagem competitiva. O valor de uma marca possui um papel extremamente importante em uma decisão de compra, visto que quanto mais conhecida pelo consumidor, maior é a relação com o mesmo. Nesse sentido, o consumidor tende confiar em marcas que foram responsáveis por fazer que ele tenha tido uma experiência satisfatória. Tal relação faz com que essas marcas sejam mais contempladas pelos consumidores no momento da compra, gerando então, uma ampla vantagem competitiva frente a outras marcas. De acordo com Kotler (2006), o produto ou oferta alcançará êxito se proporcionar valor e satisfação ao comprador-alvo. O comprador escolhe entre diferentes ofertas com base naquilo que parece proporcionar o maior valor.

\subsection{Comportamento do consumidor}

De acordo com Kotler (2006), a área do comportamento do consumidor estuda como pessoas, grupos e organizações selecionam, compram, usam e descartam produtos, 
serviços, ideias ou experiências para satisfazer as suas necessidades e os seus desejos. Segundo o Santander Negócios e Empresas (2017), os clientes do tempo atual têm pressa e não querem ficar para trás. Querem serviços rápidos, mas ao mesmo tempo com extrema qualidade.

Para Churchill e Peter (2000), o comportamento do consumidor busca entender o motivo que leva os consumidores a comprarem certos produtos e não outros e para isso os profissionais de marketing estudam os pensamentos, sentimentos, ações dos consumidores e influências sobre eles que determinam mudanças. Para Kotler e Keller (2006), uma vez que o propósito do marketing é centrado em atender e satisfazer às necessidades e aos desejos dos consumidores, torna-se fundamental conhecer o seu comportamento de compra.

Para Kotler (2006), uma pessoa motivada está pronta para agir e a influência da percepção que ela tem da situação é o ponto inicial. Nesse sentindo, pode-se observar a importância do estudo do comportamento do consumidor para as prestadoras de serviço em relação à utilização de seus serviços, já que, com a obtenção de informações precisas e quantificáveis sobre os comportamentos de seus clientes, uma empresa pode desenhar melhor seus serviços e processos, sendo capaz, então, de atender as necessidade e vontades dos consumidores. Como consequência, será mais fácil a obtenção de melhores resultados de vendas e maio lucro.

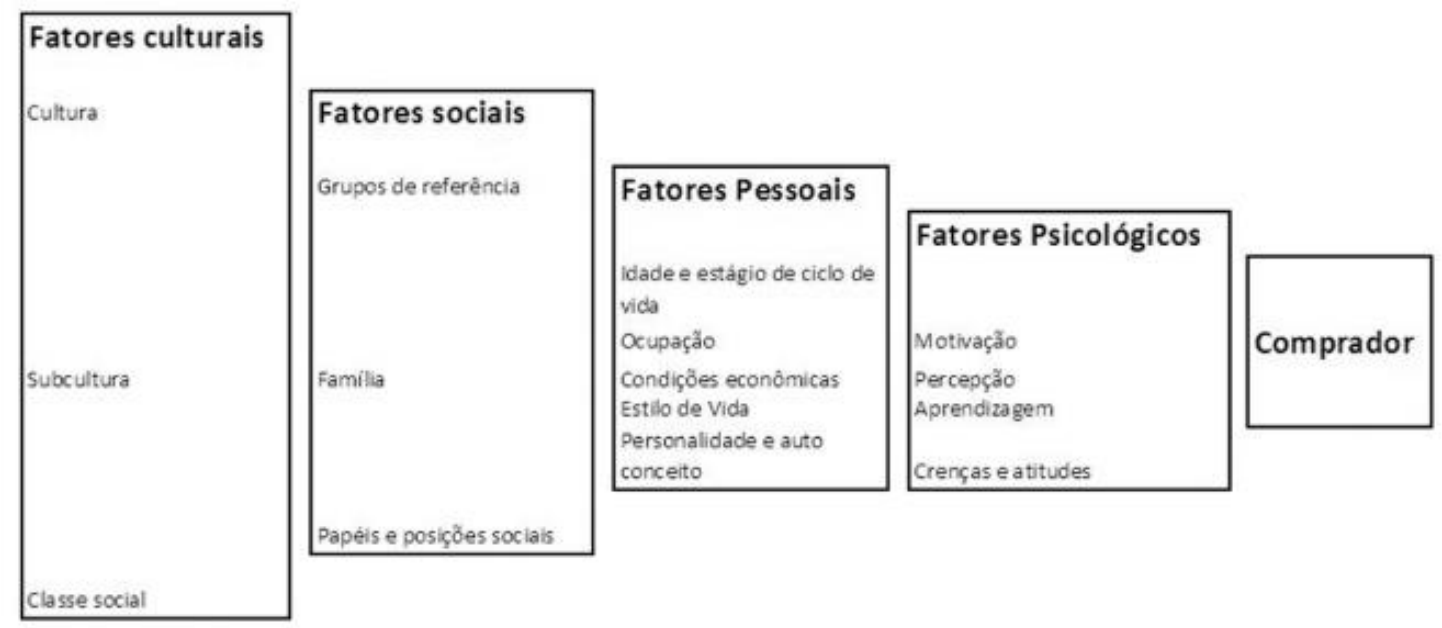

Figura 3 - Modelo de comportamento de compra

Fonte: KOTLER, ARMSTRONG (1993)

Segundo Kotler e Armstrong (1993), as decisões de aquisição de um consumidor são profundamente influenciadas por características culturais, sociais, pessoais e psicológicas como mostra na figura 3. Kotler e Armstrong (1993) afirma que a cultura é o determinante 
mais fundamental dos desejos e do comportamento de uma pessoa. Os fatores culturais são os que exercem a mais ampla e profunda influência sobre o comportamento do consumidor. Kotler e Armstrong (1998) sustenta que cada cultura consiste em subculturas menores, as quais fornecem identificação mais específica e socialização para os seus membros. Podemse citar como subcultura religiões e nacionalidades, por exemplo. Para o autor, classes sociais são divisões relativamente homogêneas e duradouras de uma sociedade, que são ordenadas hierarquicamente e cujos membros compartilham valores, interesses e comportamentos similares.

Para Kotler e Armstrong (1993), os fatores sociais envolvem os grupos de referência com os quais o indivíduo tem contato, como família, papéis e posições sociais que acabam por influenciar o comportamento de compra. Para Kotler e Armstrong (1993), Os grupos de referência são aqueles grupos de pessoas que influenciam os pensamentos, os sentimentos e os comportamentos do consumidor. De acordo com os autores, os membros da família constituem o grupo primário de referência de maior influência. Em relação a papéis e posições sociais, Kotler e Armstrong (1993) afirma que os consumidores escolhem os seus produtos que comunicam seu papel e status na sociedade que estão inseridos.

Em relação aos fatores pessoais, Kotler e Armstrong (1993) os divide em cinco elementos, que são: idade e estágio do ciclo de vida, ocupação, condições econômicas, estilo de vida e personalidade. Sobre a idade e estágio do ciclo de vida, para o autor, as necessidades e os desejos das pessoas modificam-se ao longo de suas vidas. Ocupação representa o fato de o trabalho dos consumidores influenciar os seus padrões de consumo. Segundo Kotler e Armstrong (1993), um presidente de empresa irá comprar itens como: ternos caros, passagens aéreas, títulos de clube e um grande veleiro. As condições econômicas são os elementos disponíveis pelo consumidor (poupança, crédito e etc), que afetam a escolha de produtos. O estilo de vida é relevante, pois é possível que empresas se posicionem no mercado fazendo associações entre seus produtos e o estilo de vida de consumidores reais e potenciais e a personalidade é uma variável importante para análise do comportamento do consumidor (Kotler e Armstrong, 1993).

De acordo com Kotler e Armstrong (1993) a motivação é um motivo ou impulso, que leva uma pessoa a agir. Já a percepção é a forma que uma pessoa seleciona, organiza e interpreta as informações para criar um quadro significativo do mundo. A aprendizagem é o conjunto de todas as mudanças ocasionadas no comportamento de um indivíduo em função de suas experiências. E crenças e atitudes é um pensamento descritivo que uma pessoa sustenta sobre algo. 


\subsection{Marketing de serviços}

De acordo com Kotler e Keller (2006), Marketing significa administrar mercados para dar oportunidade a trocas e relacionamentos, com o propósito de criar valor e satisfazer necessidades e desejos. Para ele, para que a empresa consiga atingir as metas organizacionais é preciso determinar as necessidades e desejos dos mercados-alvo e proporcionar a satisfação desejada de forma mais eficaz e eficiente que seus concorrentes. Destaca que serviço é toda atividade ou beneficio essencialmente intangível, que uma parte pode oferecer a outra e que não resulte na posse de algum bem.

O marketing de serviços está relacionado com o fato de a organização realizar a prestação do serviço com qualidade, atendendo o desejo do consumidor. Para Kotler e Keller (2006), para uma empresa controlar a qualidade de seu serviço, ela deve ter excelência em três áreas abrangentes: marketing externo, interno e interativo.

- Marketing interno: o processo de treinamento e motivação feito com os colaboradores para que atendam bem aos clientes.

- Marketing externo: descreve o processo normal de preparo, determinação de preço, distribuição e promoção de um serviço aos clientes.

- Marketing Interativo: a habilidade dos colaboradores em servir ao cliente.

Kolter e Keller (2006) acrescentam que se o serviço percebido não atender às expectativas dos clientes, os mesmos perderão o interesse pelo fornecedor prestador do serviço. Já se o serviço prestado atender ou superar as expectativas, os clientes ficarão inclinados a consumirem novamente do fornecedor. Segundo Churchill e Peter (2000), os profissionais de marketing de serviços, na maioria das vezes, devem manter um relacionamento contínuo com seus clientes. Para eles, o sucesso de uma organização de serviços muitas vezes depende da capacidade de desenvolver esta relação com os clientes. 


\section{Metodologia}

\subsection{Tipo de Pesquisa}

Foi utilizada pesquisa do tipo descritiva. De acordo com Vergara (2016), pesquisa descritiva é aquela que expõe características claras e bem delineadas de determinada população ou fenômeno, para isso envolve técnicas padronizadas e bem estruturadas de coleta de seus dados. Segundo Churchill e Peter (2000), a pesquisa descritiva é o estudo da frequência com que algo ocorre ou relação, caso exista alguma, entre duas variáveis.

O intuito da pesquisa feita foi medir o valor de marca da empresa de telecomunicações Oi e suas relações com o Brand Equity (lealdade à marca consciência do nome, qualidade percebida, associações da marca e outros ativos da empresa).

\subsection{Universo e amostra da pesquisa}

O universo da pesquisa é constituído por clientes da operadora de telefonia Oi. A amostra utilizada foi de 104 respondentes e todos eles residentes da cidade do Rio de Janeiro. O método utilizado de amostragem foi não probabilístico - abordagem por conveniência, com o intuito de atingimento do maior número de pessoas.

\subsection{Coleta de dados}

Para a facilitação da aplicação do modelo, foi criado um questionário de perguntas fechadas (Anexo 1) por meio da ferramenta Google Docs. Tal questionário foi desenvolvido a partir dos conceitos de Brand Equity de Aaker (1998) com o intuito de medir o valor da marca Oi para clientes da operadora que residem no Rio de Janeiro. O questionário foi distribuído e replicado em grupos de redes sociais, como Whatsapp, Linkedin e Facebook. Foi solicitado aos indivíduos que responderam ao questionário que repassassem para outras pessoas residentes do Rio de Janeiro de seu alcance.

Os respondentes numeraram as respostas de 1 a 5 , sendo 1 concordo totalmente e 5 discordo totalmente com a afirmação em questão. Quanto menor o número escolhido, maior a discordância e quanto maior o número, maior o grau de concordância do respondente.

Para realizar a coleta de dados e facilitar a interpretação dos mesmos foram gerados gráficos e tabelas, que serviram de ilustração dos resultados encontrados na pesquisa. 


\subsection{Tratamento dos dados}

Foi utilizada a abordagem quantitativa, que prioriza fornecer informações numéricas. Este método foi escolhido com o intuito da obtenção de um retorno numérico do Brand Equity da operadora Oi.

O tratamento dos dados foi feito utilizando estatística descritiva, sendo a média ponderada a principal medida utilizada. O cálculo da média ponderada foi utilizado para medir cada característica (lealdade à marca consciência do nome, qualidade percebida, associações da marca e outros ativos da empresa) do Brand Equity da marca Oi para seus clientes do Rio de Janeiro.

Para calcular as médias e gerar os gráficos comparativos, foram criadas tabelas utilizando o software Excel. Para cada questão de cada categoria do Brand Equity foi criado um gráfico diferente e para a análise final foi criado um gráfico único, consolidando todas as questões de cada categoria do Brand Equity.

\subsection{Limitações do método}

O método utilizado na pesquisa não é capaz de medir se a pessoa que respondeu ao questionário usou de parcialidade. Assim como não é possível identificar se as respostas foram enviesadas por conta de algum problema ou grande benefício gerado para o cliente pela operadora de telefonia Oi. 


\section{Análise de resultados}

\subsection{Perfil dos respondentes}

A parte inicial do questionário foi composta por questões com o intuito de identificar o perfil dos respondentes. A primeira questão verificava a operadora de telefonia dos respondentes, os que não eram clientes Oi não seguiam com as respostas. Seguiram apenas os clientes $\mathrm{Oi}$. As questões seguintes faziam a verificação de faixa etária, gênero, grau de escolaridade e renda dos respondentes.

Gráfico 1 - Idade dos respondentes

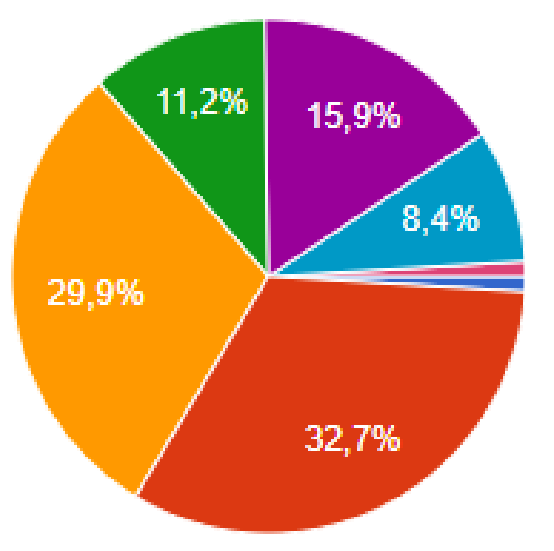

Menos que 18 anos

Entre 18 e 24 anos

Entre 25 e 31 anos

Entre 32 e 38 anos

Entre 39 e 45 anos

Entre 46 e 52 anos

Mais que 52 anos

Fonte: Pesquisa de campo (2019)

Nota-se um perfil bastante variado em relação às idades dos respondentes do questionário. A maioria possui entre 18 e 24 e entre 25 e 31 com 32,7\% e 29,9\% respectivamente. $15,9 \%$ possuem entre 39 e 45 anos, $11,2 \%$ possuem entre 32 e $38 \%$ e o menor percentual são de pessoas entre 46 e 52 anos, com 8,4\%. 


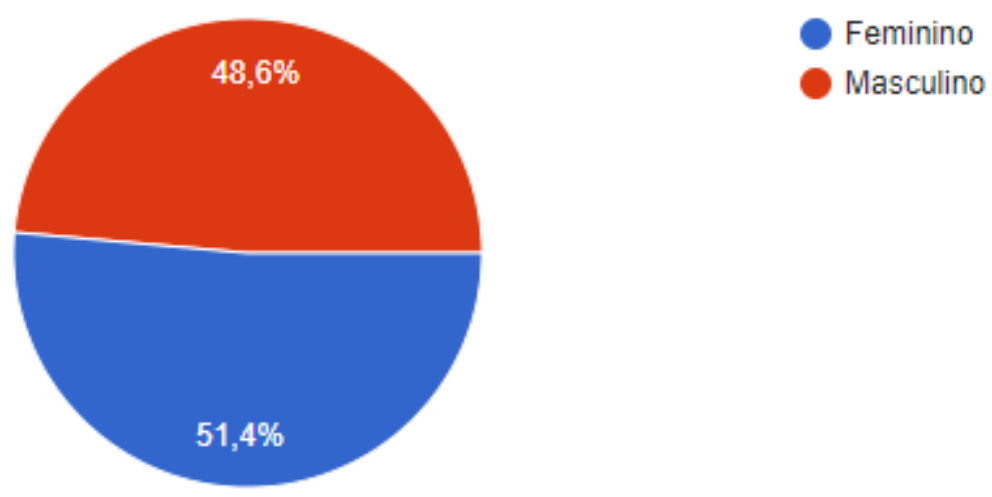

Fonte: Pesquisa de campo (2019)

Em relação ao gênero, é possível observar bastante equilíbrio entre os sexos. $O$ sexo feminino representou $51,4 \%$ do total de respondentes e o masculino $48,6 \%$.

Gráfico 3 - Nível de escolaridade dos respondentes

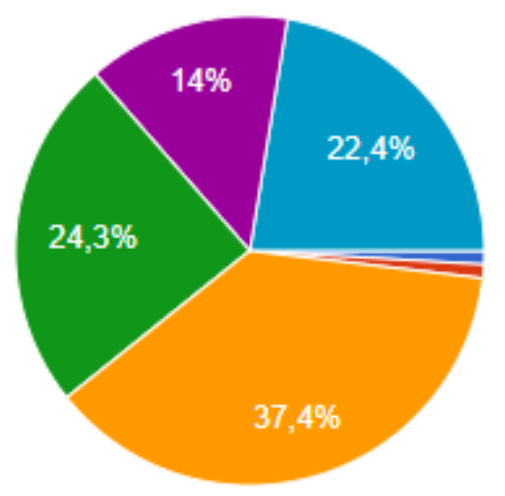

Ensino Médio incompleto

Ensino Médio completo

Ensino Superior incompleto

Ensino Superior completo

Pós-Graduação incompleta

Pós-Graduação completa

Fonte: Pesquisa de campo (2019)

A maior parte das pessoas que responderam ao questionário, representada por $37,4 \%$ do total, possui o ensino superior incompleto. Em seguida, 24,3\% possuem ensino superior completo, 22,4\% possuem pós-graduação completa e por fim, 14\% possuem pósgraduação incompleta. 


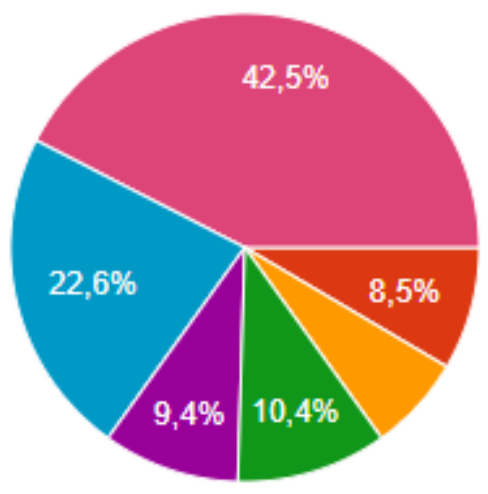

Menos que R\$ 998,00

De R\$ 998,00 até R\$2.2994,00

De R\$ 2.2994,00 até R\$ 5.988,00

De $R \$ 5.988,00$ até $R \$ 8.982,00$

De R\$ 8.982,00 até R\$ 11.976,00

De R\$ $11.976,00$ até R\$ $14.970,00$

Mais que R\$ $14.970,00$

Fonte: Pesquisa de campo (2019)

Em primeiro lugar, 42,5\% dos respondentes do questionário responderam que a renda familiar mensal é superior a $R \$ 14.970,00$. Já $22,6 \%$ afirmaram que as suas tendas estão entre $R \$ 11,976,00$ até $R \$ 14.970,00$. Em terceiro lugar, 10,4\% dos respondentes afirmaram que sua renda familiar está entre $R \$ 5.988,00$ e $R \$ 8.982,00,9,4$ entre $R \$$ $8.982,00$ e $R \$ 11.976,00$ e $8,5 \%$ entre $R \$ 998,00$ e $R \$ 2.299,00$, estando em terceiro e quarto lugar respectivamente.

Gráfico 5 - Antiguidade do cliente na empresa Oi

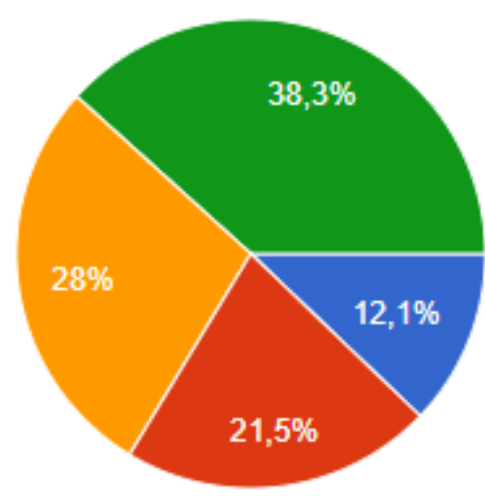

Fonte: Pesquisa de campo (2019)

Nota-se que a maioria dos respondentes são clientes antigos da empresa Oi. Apenas $12,1 \%$ são clientes há 1 ano ou menos. 


\subsection{Lealdade à marca}

O composto lealdade à marca foi dimensionado a partir das questões:

- Sou leal à operadora Oi.

- Não trocaria a operadora Oi por outra concorrente, mesmo se a concorrente me der os mesmo benefícios que possuo.

- Não trocaria a operadora Oi por outra concorrente, mesmo se a concorrente me der melhores benefícios que possuo.

Gráfico 6 - Sou leal à operadora Oi

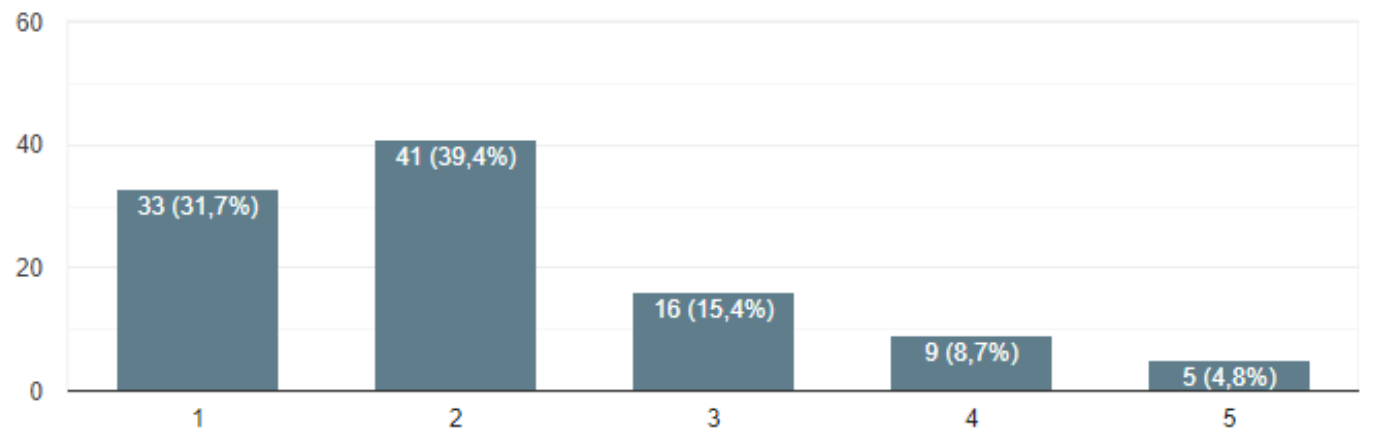

Legenda: 1 - nível mínimo de concordância

5 - nível máximo de concordância

Fonte: Pesquisa de campo (2019)

Gráfico 7 - Não trocaria a operadora Oi por outra concorrente, mesmo se a concorrente me der os mesmos benefícios que possuo

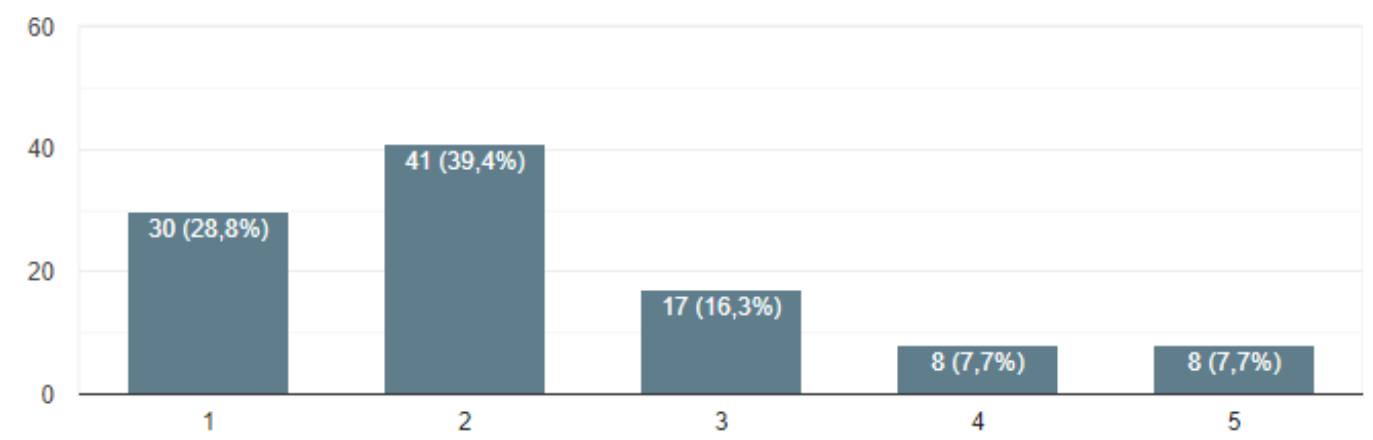

Legenda: 1 - nível mínimo de concordância

5 - nível máximo de concordância

Fonte: Pesquisa de campo (2019) 
Gráfico 8 - Não trocaria a operadora Oi por outra concorrente, mesmo se a concorrente me der melhores benefícios que possuo

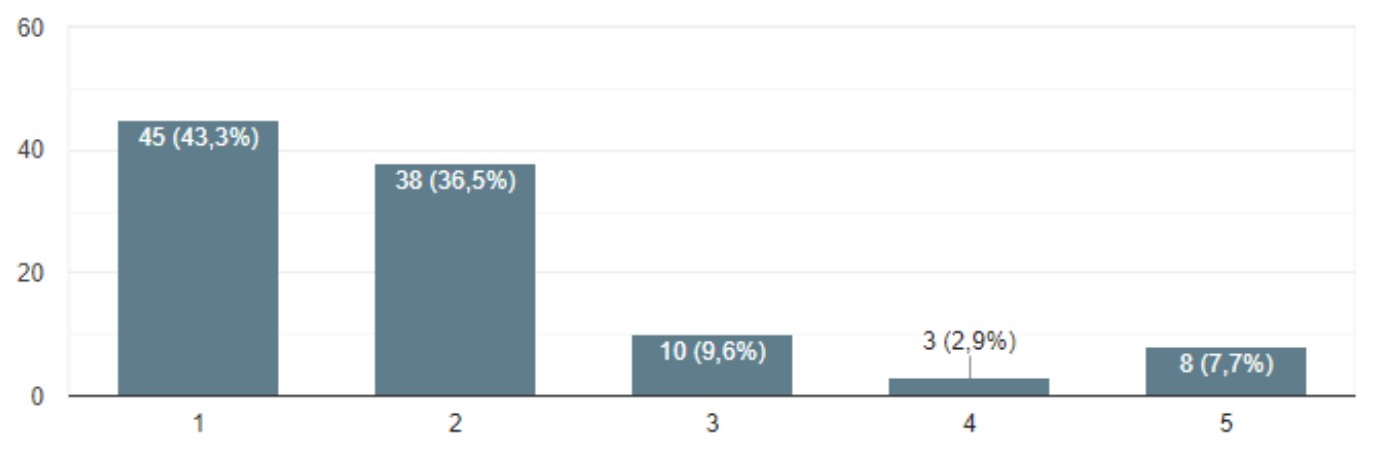

Legenda: 1 - nível mínimo de concordância

5 - nível máximo de concordância

Fonte: Pesquisa de campo (2019)

Conforme abordado no tópico 2.1, a lealdade é de extrema importância, pois é a capacidade de manter o cliente cativo mesmo com toda a concorrência e ofertas semelhantes. Em relação à lealdade à operadora $\mathrm{Oi}$, a grande maioria dos respondentes discordou totalmente, 79\% dos respondentes marcaram as opções 1 e 2 (Gráfico 6). Quanto maior a pontuação, maior disposição de a empresa Oi assegurar a sua base de clientes de forma invariável. De acordo com as respostas, os clientes não são leais à operadora Oi e estão dispostos a trocar de operadora. Mais da metade dos respondentes (28,8\% opção 1 e 39,4\% opção 2) trocariam a operadora Oi por outra concorrente, mesmo se a concorrente oferecer os mesmos benefícios dados pela Oi (Gráfico 7) e esse número aumenta ainda mais se a concorrente oferecer benefícios melhores (43,3\% opção 1 e 36,5\% opção 2) (Gráfico 8).

Seguindo o que foi abordado no tópico 2.4, se o serviço prestado atender ou superar as expectativas, os clientes ficarão inclinados a consumirem novamente. Assim, a Oi precisa investir em distintas ações para conquistar a lealdade de seus clientes, manter-se coberta e garantir uma base estável de clientes.

\subsection{Consciência do nome}

O composto consciência do nome foi verificado a partir das três questões abaixo: 
- Conheço todos os serviços oferecidos pela operadora Oi.

- Conheço o posicionamento de marca da operadora Oi.

- Conheço as causas apoiadas pela operadora Oi.

Gráfico 9 - Conheço todos os serviços oferecidos pela empresa Oi

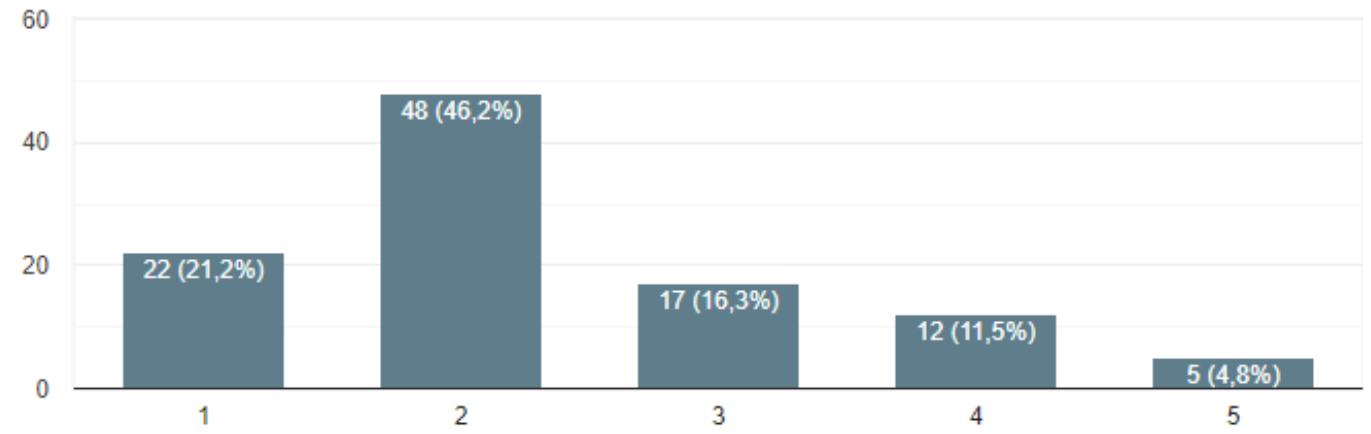

Legenda: 1 - nível mínimo de concordância

5 - nível máximo de concordância

Fonte: Pesquisa de campo (2019)

Gráfico 10 - Conheço posicionamento de marca da operadora Oi

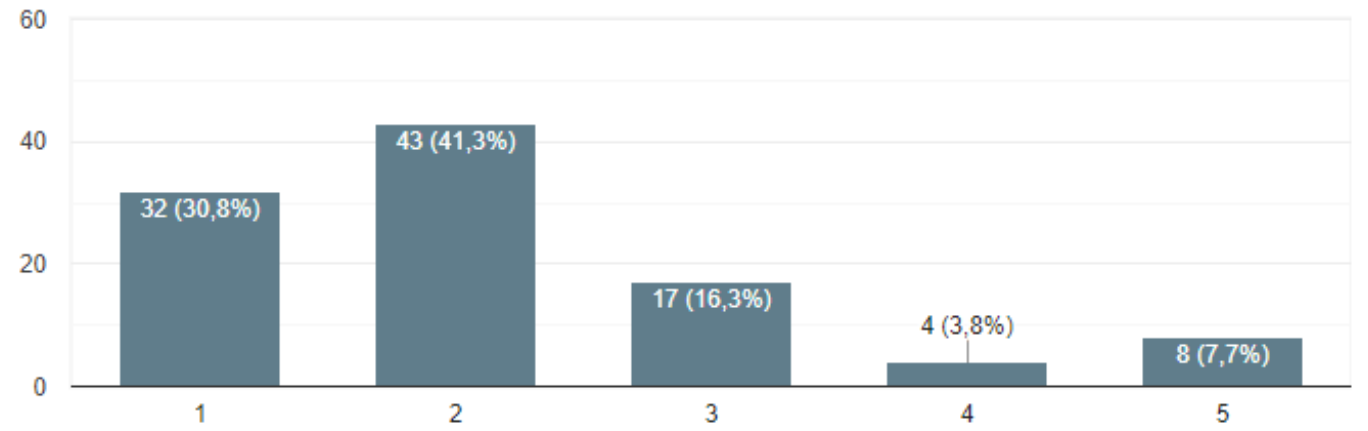

Legenda: 1 - nível mínimo de concordância

5 - nível máximo de concordância

Fonte: Pesquisa de campo (2019) 
Gráfico 11 - Conheço as causa apoiadas pela operadora Oi

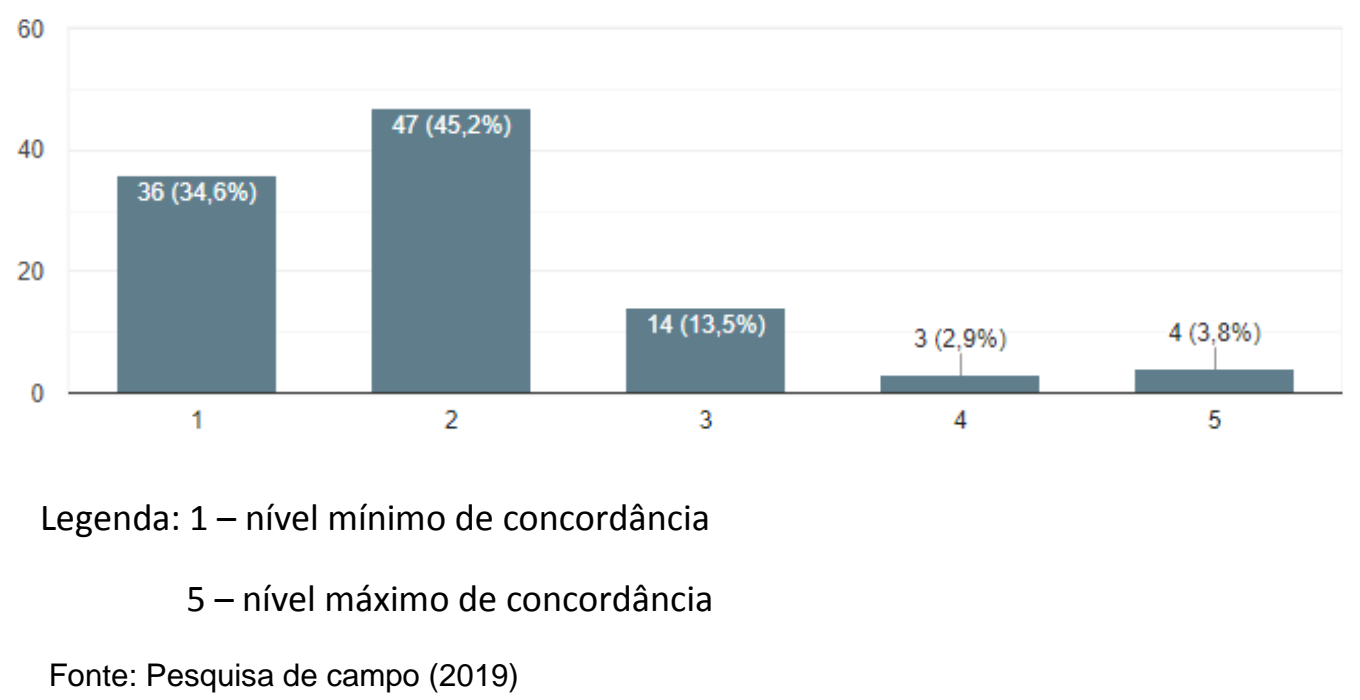

Uma empresa com pontuação baixa nesse composto não possui o reconhecimento dos consumidores relacionados à sua marca, tendo, então, menos chance de ser top of mind, conforme citado no tópico 2.1. Tal fato é bastante preocupante para a empresa Oi, já que os próprios clientes da empresa responderam de forma bastante negativa às questões relacionadas a esse tema. De acordo com o Gráfico 9, 67,4\% responderam que não conhecem todos os serviços oferecidos pela operada (21,2\% responderam 1 e $46,2 \%$, 2). Em relação ao posicionamento da marca (Gráfico 10), 30,8\% e 41,3\% optaram pelas respostas 1 e 2, respectivamente, ou seja, discordam totalmente da afirmação. Sobre a questão associada ao conhecimento de causas apoiadas pela operadora, o cenário foi bastante semelhante, $79,8 \%$ marcaram as opções 1 e 2, ou seja, discordam totalmente da afirmação em questão (Gráfico 11).

\subsection{Qualidade percebida}

O composto qualidade percebida foi medido por meio das três questões abaixo:

- A operadora Oi possui diferenciais superiores aos seus concorrentes.

- Os planos da operadora Oi dão mais vantagens que os das concorrentes.

- O serviço prestado pela operadora Oi é superior ao das concorrentes. 
Gráfico 12 - A operadora Oi possui diferenciais superiores aos seus concorrentes

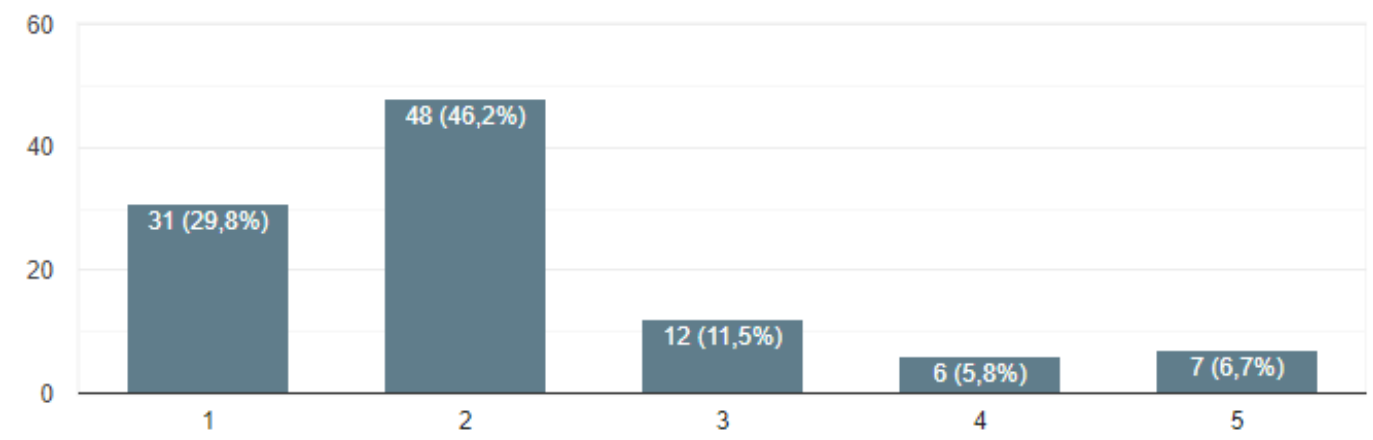

Legenda: 1 - nível mínimo de concordância

5 - nível máximo de concordância

Fonte: Pesquisa de campo (2019).

Gráfico 13 - Os planos da operadora Oi dão mais vantagens que os das concorrentes

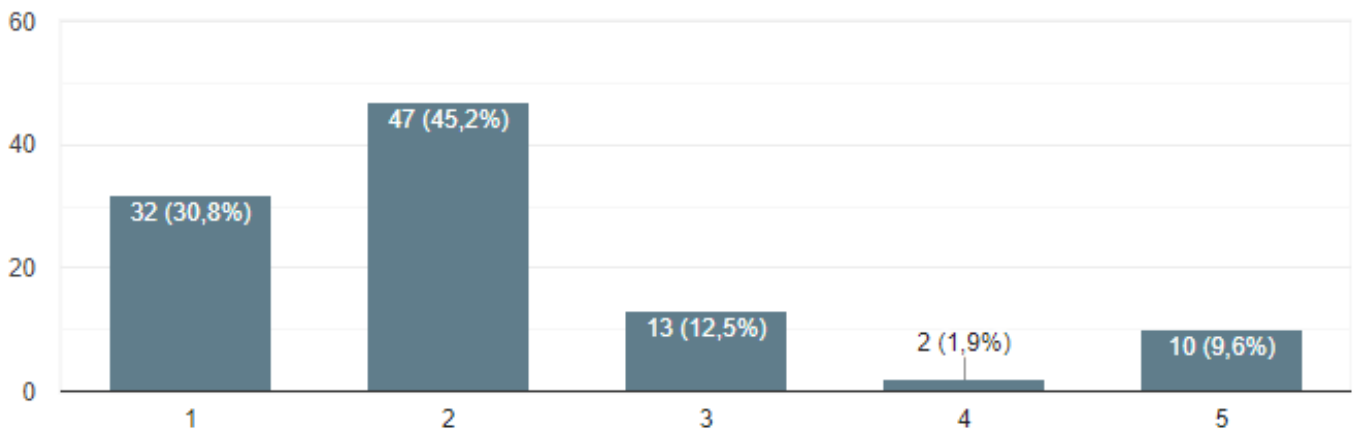

Legenda: 1 - nível mínimo de concordância

5 - nível máximo de concordância

Fonte: Pesquisa de campo (2019) 
Gráfico 14 - O serviço prestado pela operadora Oi é superior ao das concorrentes

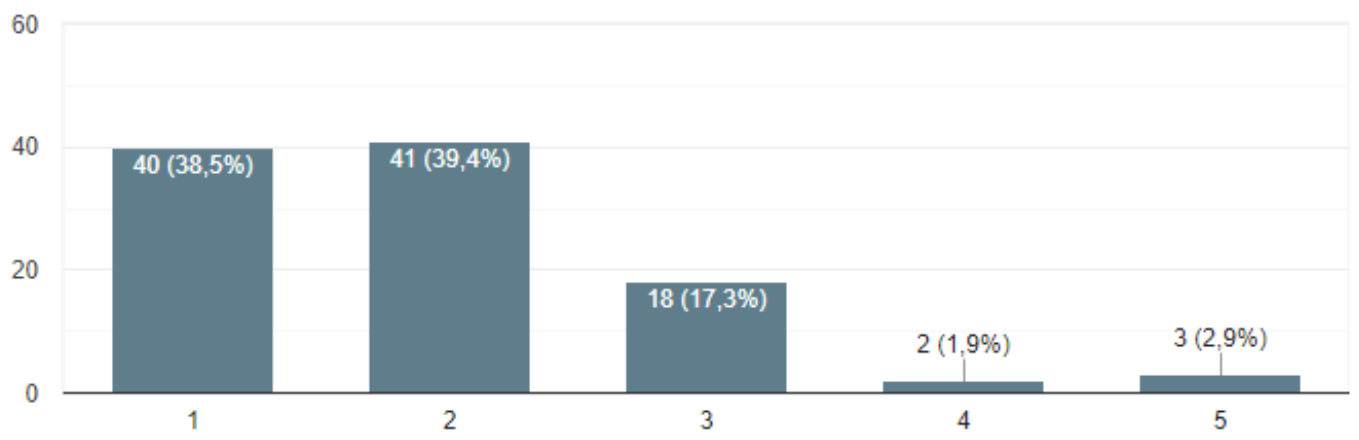

Legenda: 1 - nível mínimo de concordância

5 - nível máximo de concordância

Fonte: Pesquisa de campo (2019)

Ter uma pontuação alta nesse quesito é o resultado de os clientes possuírem uma percepção positiva do serviço prestado pela operadora e entenderem que ele é de alta qualidade. O resultado da pesquisa mostrou que os clientes da operadora Oi não acreditam que os serviços oferecidos por ela são superiores aos dos concorrentes (Gráfico 12) (29,8\% optaram pela opção 1 e 46,2\% pela opção 2), mais de 70\% discordam do fato de os planos da operadora Oi darem mais vantagens que os oferecidos pelas concorrentes (Gráfico 13) e $77,9 \%$ acreditam que o serviço prestado pela operadora não é superior ao das concorrentes (38,5\% marcaram a opção 1 e 39,4\% a opção 2) (Gráfico 14). Dessa forma, entende-se que os respondentes possuem uma expectativa maior a respeito da qualidade do serviço prestado do que de fato a operadora Oi oferece a eles

\subsection{Associações da marca}

O composto associações da marca foi medido por meio das três questões abaixo:

- Conheço a logo da operadora Oi.

- Conheço o slogan da operadora Oi.

- Sei dizer qual é o comercial de TV atual da empresa Oi. 
Gráfico 15 - Conheço a logo da operadora Oi

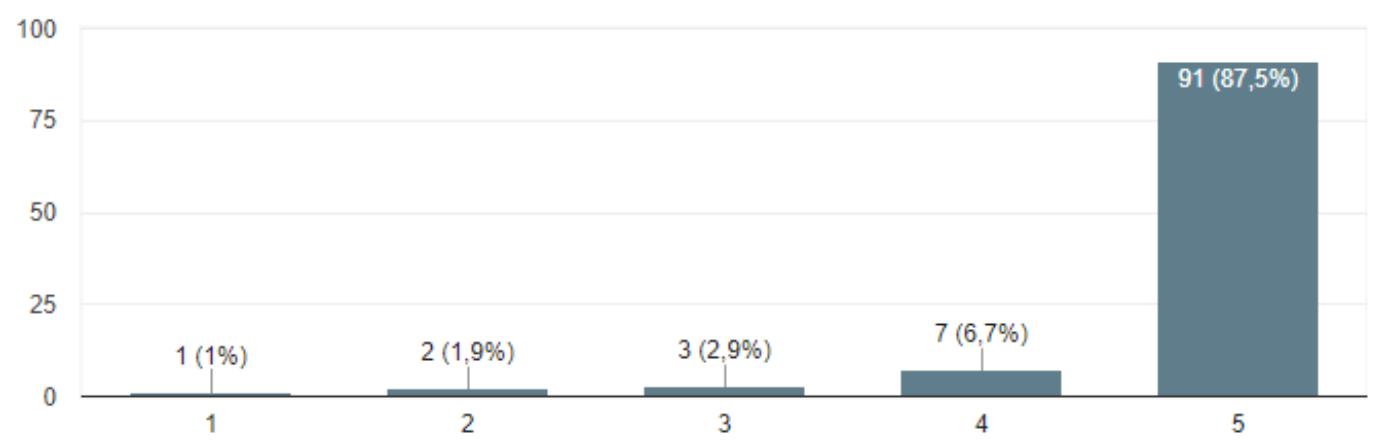

Legenda: 1 - nível mínimo de concordância

5 - nível máximo de concordância

Fonte: Pesquisa de campo (2019)

Gráfico 16 - Conheço o slogan da operadora Oi

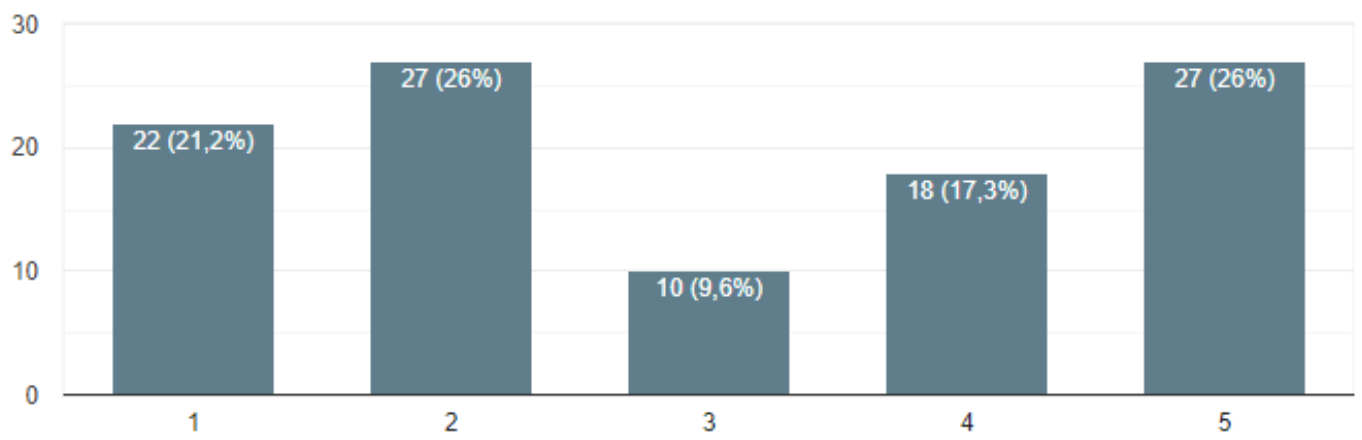

Legenda: 1 - nível mínimo de concordância

5 - nível máximo de concordância

Fonte: Pesquisa de campo (2019) 
Gráfico 17 - Sei dizer qual é o comercial de TV atual da operadora Oi

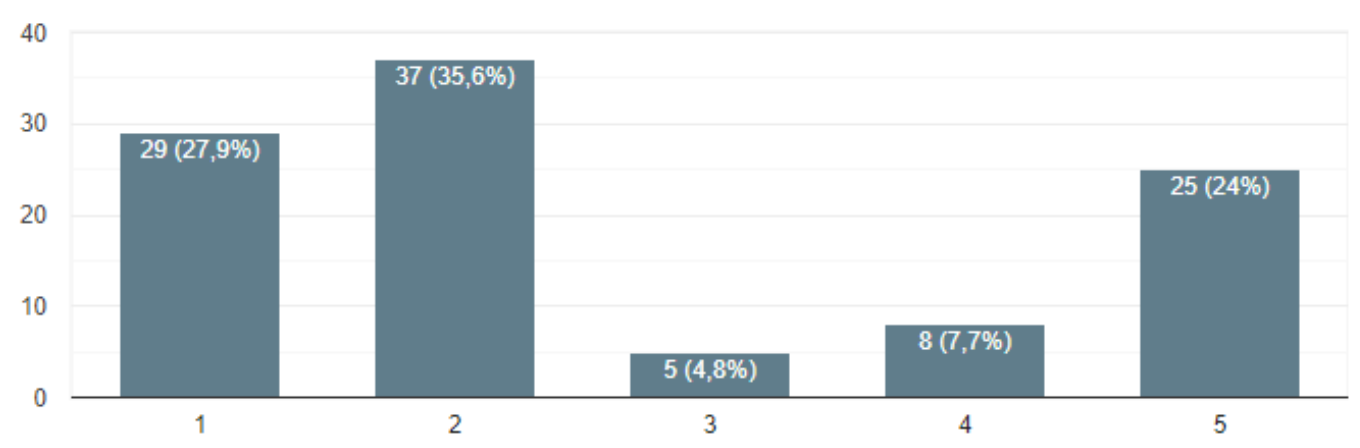

Legenda: 1 - nível mínimo de concordância

5 - nível máximo de concordância

Fonte: Pesquisa de campo (2019)

A grande maioria dos respondentes marcou a opção 4 e 5 em relação ao conhecimento da logo da operadora Oi (Gráfico 15) (87,5\% optaram por 5 e 6,7\% por 4). Isso mostra que a logo é um ponto bastante positivo para a empresa estudada. Como citado no tópico 2.2, a marca é capaz de diferenciar um produto/serviço de outro existente; entende-se então, que a logo é um diferencial para os clientes da empresa estudada. Em relação ao slogan da operadora (gráfico 16), o resultado ficou bastante equilibrado, com $47,2 \%$ optando por 1 e 2 e 43,3\% por 4 e 5 . A empresa precisa reforçar o seu slogan para este ficar conhecido por seus clientes, já que, como abordado no tópico 2.2 deste trabalho, os clientes se sentem confortáveis consumindo alguma marca que seja familiar para eles. Em relação ao comercial de TV (Gráfico 17), a grande maioria respondeu dizendo que não conhece (63,5\% optaram por 1 e 2 e apenas $31,7 \%$ por 4 e 5), o que mostra que os comerciais da operadora não estão sendo lembrados por seus clientes.

\subsection{Outros ativos da empresa}

O composto outros ativos da empresa foi medido por meio da questão abaixo:

- Sei dizer o nome de dois atletas que são ou já foram patrocinados pela 
Gráfico 18 - Sei dizer o nome de dois atletas que são ou já foram patrocinados pela empresa Oi

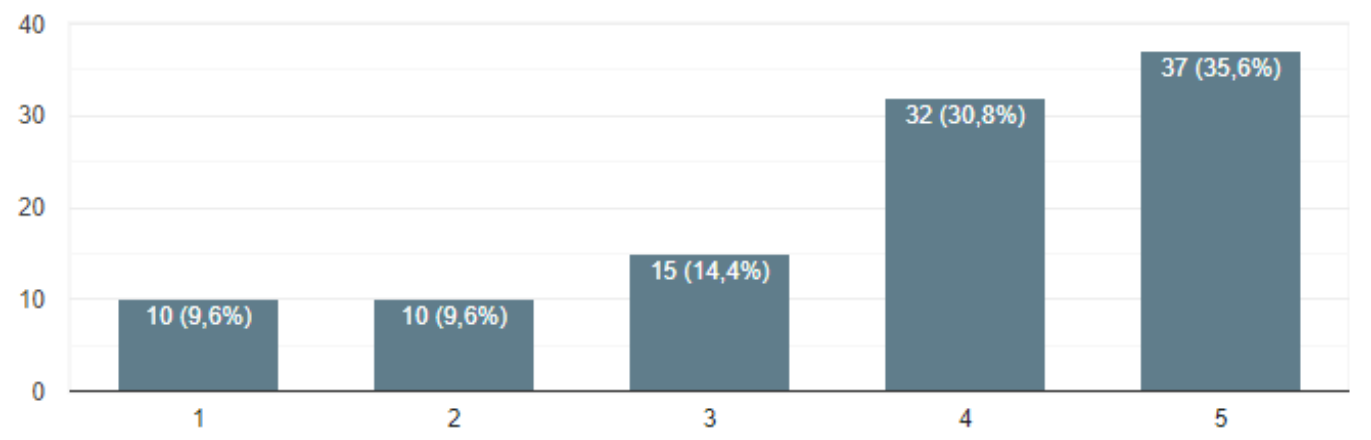

Legenda: 1 - nível mínimo de concordância

5 - nível máximo de concordância

Fonte: Pesquisa de campo (2019)

A grande maioria dos respondentes marcou as opções 4 e $530,8 \%$ e $35,6 \%$ respectivamente, somando 66,4\%. As opções 1 e 2 foram escolhidas por 19,2\% dos respondentes (9,6\% opção 1 e 9,6\% opção 2) (Gráfico 18). As opções 4 e 5 indicam que os respondentes concordam com a afirmação em questão e a 1 e 2 indicam que eles discordam com ela. Isso mostra que os atletas patrocinados pela empresa Oi estão presentes na memória dos clientes e que a empresa possui diferenciais apartados do seu serviço, que é reconhecido por seus clientes. 


\subsection{Brand Equity}

Gráfico 19: O Brand Equity da operadora Oi

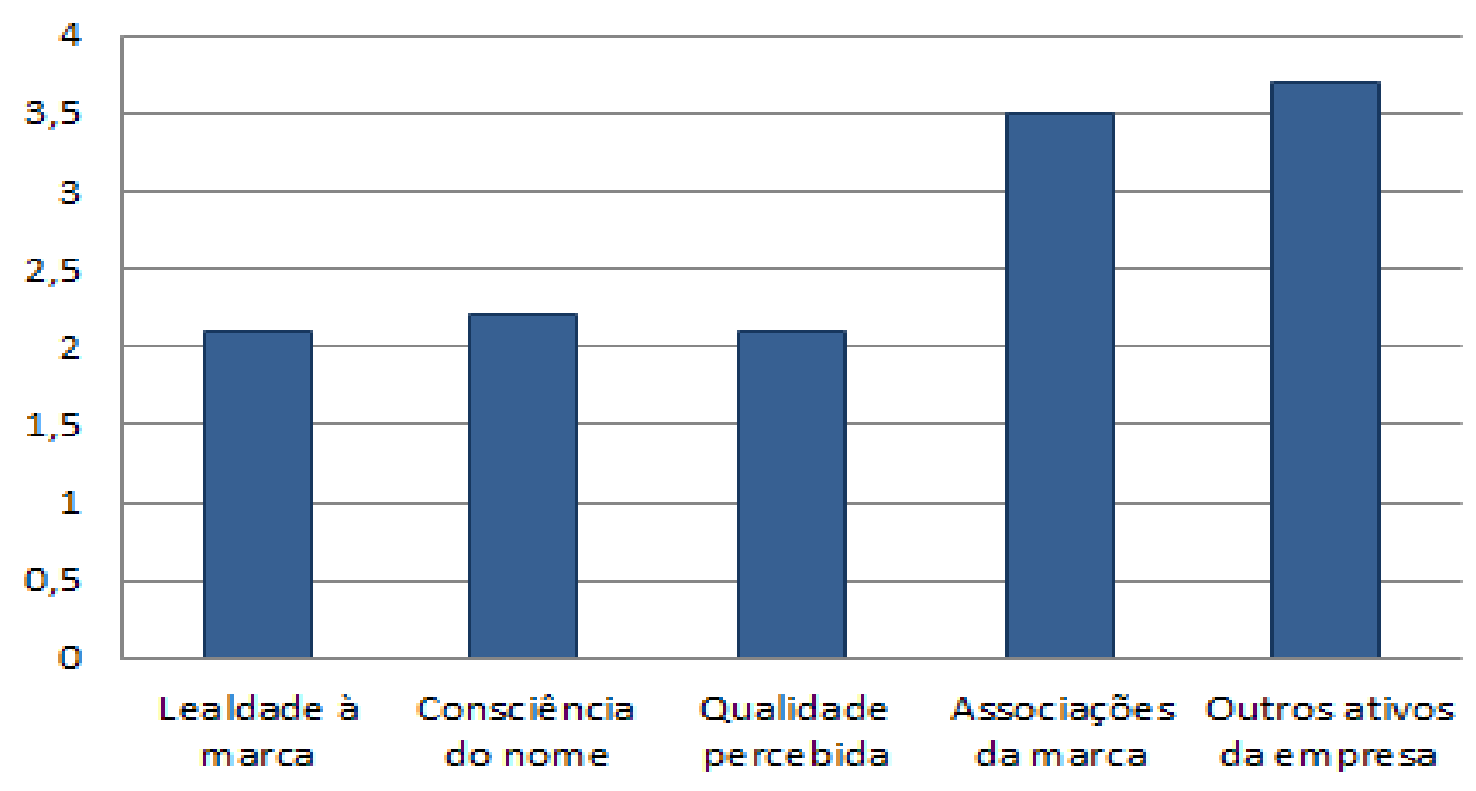

Legenda: 1 - nível mínimo

5 - nível máximo

Fonte: Pesquisa de campo (2019)

O Gráfico 19 ilustra o consolidado do Brand Equity da empresa de telefonia Oi. Os compostos lealdade à marca, consciência do nome e qualidade percebida tiveram resultados bastante baixos, a operadora deveria concentrar esforços com intuito de melhorar esses resultados. Ela pode investir na capacidade da sua rede e na prestação de seus serviços com foco em atender os clientes com alta qualidade. Associações da marca e outros ativos da empresa destacam-se pela proximidade de 5, o que ilustra a maior força da Oi nesses quesitos. A empresa deve manter o patrocínio dos atletas e investir em ações de marca que fortaleçam a marca Oi. 


\section{Conclusão}

O objetivo do presente trabalho era medir o valor da marca Oi para os seus clientes do Rio de Janeiro por meio do conceito de Brand Equity de Aaker (1998). Com base no questionário aplicado, foi possível mensurar o Brand Equity de acordo com os compostos de Aaker (1998) - lealdade à marca, consciência do nome, qualidade percebida, associações da marca e outros ativos da empresa da empresa Oi.

Conclui-se que os aspectos do Brand Equity interferem na força da marca de uma operadora de telefonia. A pesquisa resultou em números bastante baixos em quase todos os compostos, o resultado negativo coincide com a difícil fase enfrentada atualmente pela $\mathrm{Oi}$. $\mathrm{A}$ Recuperação Judicial compromete a percepção do valor da marca para os clientes e a situação financeira de dívidas dificulta a operação da empresa.

O emprego da pesquisa levou às pontuações a respeito da empresa Oi (em um máximo de 5 pontos): lealdade à marca - 2,1, consciência do nome - 2,2, qualidade percebida - 2,1, associações da marca - 3,5 e outros ativos da empresa - 3,7.Tais pontuações respondem à pergunta problema do estudo, demonstrando que o valor da marca Oi para os clientes do Rio de Janeiro é baixo.

As notas de lealdade à marca, consciência do nome e qualidade percebida foram bem inferiores a 5 . Esses números demonstram que a empresa Oi deve melhorar a forma de divulgação de seus serviços, deixar mais claro para o consumidor o seu posicionamento de marca e as causas apoiadas por ela. Ela pode fazer isso por meio de criação de melhores materiais de comunicação de oferta e de postura relacionada à sua marca, que são distribuídos nos pontos de venda e postados em suas redes sociais. Com o intuito de melhorar a qualidade percebida por seus clientes, ela pode investir no desenvolvimento de planos que de destaquem em relação à concorrência e investir em atendimento diferenciado. Dessa forma, irá alavancar o valor de sua marca na percepção de seus clientes.

As melhores notas obtidas pela empresa foram em associações da marca e em outros ativos da empresa. Importante ressaltar que o conhecimento da logo da empresa e dos atletas patrocinados por ela contribuiu positivamente com esse resultado.

A maior parte dos respondentes são clientes da operadora Oi há 3 anos ou mais. Nesse sentido, observa-se a dificuldade enfrentada pela empresa em relação à captação de novos clientes. Uma importante sugestão é o foco no relacionamento com esses clientes antigos com o intuito de não comprometer a sua base. 
A suposição gerencial do trabalho fundamenta que a empresa de telefonia Oi deve reforçar seu Brand Equity com o objetivo de fortalecer o valor da marca para os seus clientes do Rio de Janeiro. Ela deve visitar todas as cinco características estudadas e atuar em cima de suas carências para reverter esse quadro. O cenário atual instável do país e do setor de serviços complementa ainda mais a importância da atenção nesse assunto. Uma empresa que possui alto valor de marca para seus clientes tem uma marca mais forte e ganha espaço no mercado. 


\section{Referências bibliográficas}

ANATEL. Banda Larga Fixa Acessos. Rio de janeiro 2019. Disponível em: < http://www.anatel.gov.br/dados/acessos-banda-larga-fixa >. Acesso em: 13 mar. 2019.

ANATEL. Telefonia Fixa Acessos. Rio de janeiro 2018. Disponível em: < http://www.anatel.gov.br/dados/acessos-telefonia-fixa >. Acesso em: 30 nov. 2018.

AAKER, David A. Brand Equity: gerenciando o valor da marca. 10 $0^{\underline{a}}$ Ed. São Paulo: Negócio, 1998.

CHURCHIL, G. A; PETER, J. P. Marketing: criando valor para os clientes; São Paulo: Saraiva, 2000.

KOTLER, Philip e ARMSTRONG, Gary. Princípios de Marketing, 5ª Ed. Rio de Janeiro, Prentice Hall do Brasil, 2006.

KELLER, Kevin Lane. MACHADO, Marcos. Gestão Estratégica de Marcas; São Paulo: Pearson Prentice Hall. 2005

LEVY,Michael; GREWAL, Dhruv. Marketing, 4a Ed. Amgh, 2017.

Oi. Rio de Janeiro, 2019. Disponível em: < http://www.oi.com.br >. Acesso em 20 nov. 2018.

RECLAME AQUI. Rankings. Rio de Janeiro de 2019. Disponível em: <https://www.reclameaqui.com.br/ranking/>. Acesso em 13 mar. 2019

VERGARA, Sylvia Constant. Projetos e relatórios de pesquisa em administração, 16 a Ed. Atlas, 2016.

RUST. T., ZEITHAML Zeithaml, V. A., \& LEMON, K. N. (2004). O valor do cliente: o modelo que está reformulando a estratégia corporativa. Porto Alegre: Bookman, 2001. 


\section{Anexo 1 (Questionário)}

\section{Operadora}

Qual sua operadora de telefone celular?

Oi/Outras

\section{Lealdade à marca}

Sou leal à operadora Oi.

Discordo totalmente $1-2-3-4-5$ Concordo totalmente

Não trocaria a operadora Oi por outra concorrente, mesmo se a concorrente me der os mesmos benefícios que possuo.

Discordo totalmente $1-2-3-4-5$ Concordo totalmente

Não trocaria a operadora Oi por outra concorrente, mesmo se a concorrente me der melhores benefícios que possuo.

Discordo totalmente $1-2-3-4-5$ Concordo totalmente

\section{Consciência do nome:}

Conheço todos os serviços oferecidos pela operadora Oi.

Discordo totalmente $1-2-3-4-5$ Concordo totalmente

Conheço o posicionamento de marca da operadora Oi.

Discordo totalmente $1-2-3-4-5$ Concordo totalmente

Conheço as causas apoiadas pela operadora Oi.

Discordo totalmente $1-2-3-4-5$ Concordo totalmente

\section{Qualidade percebida:}

A operadora Oi possui diferenciais superiores aos seus concorrentes.

Discordo totalmente $1-2-3-4-5$ Concordo totalmente

Os planos da operadora Oi dão mais vantagens que os das concorrentes.

Discordo totalmente $1-2-3-4-5$ Concordo totalmente 
O serviço prestado pela operadora Oi é superior ao das concorrentes.

Discordo totalmente $1-2-3-4-5$ Concordo totalmente

\section{Associações da marca:}

Conheço a logo da operadora Oi.

Discordo totalmente $1-2-3-4-5$ Concordo totalmente

Conheço o slogan da operadora Oi.

Discordo totalmente $1-2-3-4-5$ Concordo totalmente

Sei dizer qual é o comercial de TV atual da operadora Oi.

Discordo totalmente $1-2-3-4-5$ Concordo totalmente

\section{Outros ativos da empresa:}

Sei dizer o nome de dois atletas que são ou já foram patrocinados pela empresa Oi.

Discordo totalmente $1-2-3-4-5$ Concordo totalmente

\section{Perfil do Respondente}

Quantos anos você tem?

- Menos que 18 anos

- Entre 18 e 24 anos

- Entre 25 e 31 anos

- Entre 32 e 38 anos

- Entre 39 e 45 anos

- Entre 46 e 52 anos

- Mais que 52 anos

Qual é o seu gênero?

- Feminino

- Masculino

Qual é o seu grau de escolaridade? 
- Ensino Médio incompleto

- Ensino Médio completo

- Ensino Superior incompleto

- Ensino Superior completo

- Pós-Graduação incompleta

- Pós-Graduação completa

Qual é a sua renda familiar mensal (considerando a renda de todos que moram com você)?

- Menos que $\mathrm{R} \$ 998,00$

- $\quad$ De $R \$ 998,00$ até $R \$ 2.2994,00$

- $\quad$ De $R \$ 2.2994,00$ até $R \$ 5.988,00$

- $\quad$ De $R \$ 5.988,00$ até $R \$ 8.982,00$

- $\quad$ De $R \$ 8.982,00$ até $R \$ 11.976,00$

- $\quad$ De $R \$ 11.976,00$ até $R \$ 14.970,00$

- Mais que $R \$ 14.970,00$

Há quantos anos você é cliente da operadora Oi?

- 1 ano ou menos

- Entre 1 e 3 anos

- Entre 3 e 5 anos

- 5 anos ou mais 